\title{
Comparative genomics of 16 Microbacterium spp. that tolerate multiple heavy metals and antibiotics
}

\author{
Deric R Learman ${ }^{\text {Corresp., }}{ }^{1}$ ， Zahra Ahmand ${ }^{1}$, Allison Brookshier ${ }^{1}$, Michael W Henson ${ }^{1}$, Victoria Hewitt ${ }^{1}$, \\ Amanda Lis ${ }^{1}$, Cody Morrison ${ }^{1}$, Autumn Robinson ${ }^{1}$, Emily Todaro ${ }^{1}$, Ethan Wologo ${ }^{1}$, Sydney Wynne ${ }^{1}$, \\ Elizabeth W Alm ${ }^{1}$, Peter S Kourtev ${ }^{1}$ \\ ${ }^{1}$ Institute for Great Lakes Research and Department of Biology, Central Michigan University, Mount Pleasant, MI, United States of America \\ Corresponding Author: Deric R Learman \\ Email address: deric.learman@cmich.edu
}

Sixteen different strains of Microbacterium spp. were isolated from contaminated soil and enriched on the carcinogen, hexavalent chromium [ $\mathrm{Cr}(\mathrm{VI})]$. The majority of the isolates (11 of the 16) were able to tolerate concentrations $(0.1 \mathrm{mM})$ of cobalt, cadmium, and nickel, in addition to $\mathrm{Cr}(\mathrm{VI})(0.5-20 \mathrm{mM})$. Interestingly, these bacteria were also able to tolerate 3 different antibiotics (ranges: ampicillin 0-16 $\mathrm{g} \mathrm{ml}^{-1}$, chloramphenicol 0-24 $\mathrm{g} \mathrm{m} \mathrm{ml}^{-1}$, and vancomycin 0-24 $\mathrm{g} \mathrm{m} \mathrm{ml}^{-1}$ ). To gain genetic insight into these tolerance pathways, the genomes of these isolates were assembled and annotated. The genomes of these isolates have some shared genes (core genome) but also have a large amount of variability. The genomes also contained an annotated $\mathrm{Cr}(\mathrm{VI})$ reductase $(c h r R)$ that could be related to $\mathrm{Cr}(\mathrm{VI})$ reduction. Further, various heavy metal tolerance (e.g. Co/Zn/Cd efflux system) and antibiotic resistance genes were identified, which provide insight into the isolates' ability to tolerate metals and antibiotics. Overall, these isolates showed a wide range of tolerances to heavy metals and antibiotics and genetic diversity, which was likely required of this population to thrive in a contaminated environment. 
1 Comparative genomics of 16 Microbacterium spp. that tolerate multiple heavy metals and 2 antibiotics

3

4 Learman, D.R. ${ }^{1 *}$, Ahmand, Z. ${ }^{1}$, Brookshier, A ${ }^{1}$, Henson, M.W. ${ }^{1}$, Hewitt, V. ${ }^{1}$, Lis, A. ${ }^{1}$, Morrison, 5 C. ${ }^{1}$, Robinson, A. ${ }^{1}$, Todaro, E. ${ }^{1}$, Wologo, E. ${ }^{1}$, Wynne, S. ${ }^{1}$, Alm, E.W. ${ }^{1}$, and Kourtev, P.S. ${ }^{1}$

$7 \quad{ }^{1}$ Institute for Great Lakes Research and Department of Biology, Central Michigan University, Mt.

8 Pleasant, MI, 48859, U.S.A.

9

$10 *$ Corresponding author: Department of Biology, 3111 Biosciences Building, Central Michigan

11 University, Mt. Pleasant, MI, 48859. Email address: deric.learman@cmich.edu

12

13

14

15

16

17

18

19 


\section{Abstract}

21 Sixteen different strains of Microbacterium spp. were isolated from contaminated soil and enriched on the carcinogen, hexavalent chromium $[\mathrm{Cr}(\mathrm{VI})]$. The majority of the isolates (11 of the 16) were able to tolerate concentrations $(0.1 \mathrm{mM})$ of cobalt, cadmium, and nickel, in addition to $\mathrm{Cr}(\mathrm{VI})(0.5$ -

$2420 \mathrm{mM}$ ). Interestingly, these bacteria were also able to tolerate 3 different antibiotics (ranges: 25 ampicillin 0-16 $\mu \mathrm{g} \mathrm{ml}^{-1}$, chloramphenicol 0-24 $\mu \mathrm{g} \mathrm{ml}^{-1}$, and vancomycin 0-24 $\mu \mathrm{g} \mathrm{ml}^{-1}$ ). To gain genetic insight into these tolerance pathways, the genomes of these isolates were assembled and annotated. The genomes of these isolates have some shared genes (core genome) but also have a large amount of variability. The genomes also contained an annotated $\mathrm{Cr}(\mathrm{VI})$ reductase $($ chrR $)$ that could be related to $\mathrm{Cr}(\mathrm{VI})$ reduction. Further, various heavy metal tolerance (e.g. $\mathrm{Co} / \mathrm{Zn} / \mathrm{Cd}$ efflux system) and antibiotic resistance genes were identified, which provide insight into the isolates' ability to tolerate metals and antibiotics. Overall, these isolates showed a wide range of tolerances to heavy metals and antibiotics and genetic diversity, which was likely required of this population to thrive in a contaminated environment.

\section{Introduction}

Heavy metals, while naturally occurring, cause harm to both human and ecosystem health.

Specifically, chromium is a mutagen and carcinogen and its presence in the environment can be natural or due to anthropogenic activities, such as industrial manufacturing (e.g. metal plating and tanneries) and mining (chromite ore) (Barak et al., 2006; Brose and James, 2010; Cheng et al., 2012). In the environment, chromium can exist as hexavalent chromium $[\mathrm{Cr}(\mathrm{VI})]$, which is soluble and more toxic, or as insoluble trivalent chromium [Cr(III)] (Bartlett, 1991; Cheng et al., 2012).

42 Thus, the redox cycling of chromium is critical to understanding its impacts on the environment. 
43 In natural systems, $\mathrm{Cr}$ (III) can be oxidized by manganese oxides and hydrogen peroxide, while

$44 \mathrm{Cr}$ (VI) can be reduced by ferrous iron and hydrogen sulfides (Brose and James, 2010; Oze et al., 45 2004; Viti et al., 2013).

46 Many bacteria are able to tolerate $\mathrm{Cr}(\mathrm{VI})$ stress based on their ability to transport it outside 47 the cell or enzymatically reduce it to the less toxic form $\mathrm{Cr}(\mathrm{III})$. The efflux pump, chrA, has been 48 associated with providing $\mathrm{Cr}(\mathrm{VI})$ resistance by transporting it outside the cell (Cervantes and 49 Ohtake, 1988; Cervantes et al., 1990; Nies et al., 1990). A 2008 study found 135 chrA orthologs 50 of this efflux pump (Ramirez-Diaz et al., 2008), however, the presence of $\operatorname{chr} A$ is not always a sole 51 predictor of the amount of $\mathrm{Cr}(\mathrm{VI})$ that bacteria can resist (Henne et al., 2009a). Bacteria can also 52 have additional efflux pumps that provide resistance to other metals (Nies, 2003; Silver, 1996), 53 which is advantageous as anthropogenically impacted sites are often contaminated with multiple 54 stressors. Further, there is a well-known association between metal and antibiotic tolerance 55 (Baker-Austin et al., 2006; Seiler and Berendonk, 2012; Wright et al., 2006). For example, 56 Staphylococcus species use multiple efflux pumps to tolerate chromium, lead, and penicillin 57 (Ghosh et al., 2000) and Salmonella abortus equi strains were able to tolerate chromium, cadmium, 58 mercury and ampicillin (Ug and Ceylan, 2003). Thus, efflux pumps can play a vital role in how 59 bacteria thrive in contaminated ecosystems.

60 Bacteria are also known to catalyze the reduction of $\mathrm{Cr}(\mathrm{VI})$ aerobically. Specifically, certain 61 bacteria use a soluble NADH/NADPH dependent oxidoreductase to reduce Cr(VI) (Ackerley et 62 al., 2004a; Barak et al., 2006; Cheung and Gu, 2007; Gonzalez et al., 2005; Park et al., 2000). Two 63 well-studied $\mathrm{Cr}(\mathrm{VI})$ reductases are chrR and yieF. In Pseudomonas putida, chrR reduces $\mathrm{Cr}(\mathrm{VI})$ 64 via the transfer of one electron, generating $\mathrm{Cr}(\mathrm{V})$, a reactive intermediate, which then requires a 65 second electron transfer to generate the more stable insoluble Cr(III) (Park et al., 2000). 
66 Conversely, E. coli uses $y i e F$ to catalyze the transfer of four electrons to reduce $\mathrm{Cr}(\mathrm{VI})$ (Ackerley

67 et al., 2004b; Barak et al., 2006; Ramirez-Diaz et al., 2008).

68 The objective of this study was to examine the genomes of 16 Microbacterium spp. strains isolated

69 from metal contaminated soil to identify their genetic potential and physiological ability to reduce

$70 \mathrm{Cr}(\mathrm{VI})$ and to tolerate both heavy metals and antibiotics. A recent genomic study of four $\mathrm{Cr}(\mathrm{VI})$

71 reducing Microbacterium spp. identified two putative reductases (Henson et al., 2015), one

72 genetically similar to chrR in Thermus scotoductus (Opperman et al., 2008) and the other to yieF

73 of Arthrobacter sp. RUE61a (Niewerth et al., 2012), however, these putative reductases had low

74 sequence similarity to the well-studied reductases found in P. putida and E. coli. While other

75 studies have shown Microbacterium isolates are able to reduce Cr(VI) (e.g. Humphries et al., 2005;

76 Liu et al., 2012; Pattanapipitpaisal et al., 2001; Soni et al., 2014), there are still unknowns related

77 to the genetics of $\mathrm{Cr}(\mathrm{VI})$ reduction and resistance. Further, the study by Henson et al. (2015)

78 documented high levels of genomic variability between the isolates, which might be related to

79 ecotypes. However, the conclusions of this study were limited based on the low number of

80 genomes examined. Comparative genomics has been used in various environments and

81 microorganisms to examine inter-strain variation and ecotypes (e.g. Briand et al., 2009; Coleman

82 and Chisholm, 2010; Denef et al., 2010; Frangeul et al., 2008; Humbert et al., 2013; Martiny et al.,

83 2006; Meyer and Huber, 2014; Meyer et al., 2017). Thus, this study examined the genomic and

84 physiological variability of heavy metal and antibiotic resistance of 16 Microbacterium strains

85 from the same contaminated soil environment to elucidate the potential genomic flexibility of 86 closely related strains.

87

88 Methods 
89

90

9

92

94

95

\section{Bacterial Isolation}

Isolation of Microbacterium spp. from soil is described in Kourtev et al. (Kourtev et al., 2009) and Henson et al. (Henson et al., 2015). Bill Jervis from the Indiana Department of Transport provided site access (no permit was required) and the project did not involve endangered or protected species. Briefly, contaminated soil samples were collected from a Department of Transportation site in Seymour, IN. Previous studies have documented the site was contaminated with $\mathrm{Pb}\left(1,156 \mu \mathrm{g}^{-1}\right.$ soil), $\mathrm{Cr}\left(5,868 \mu \mathrm{g}^{-1}\right.$ soil), and hydrocarbons (toluene and xylenes: $>200 \mu \mathrm{g}$ $\mathrm{g}^{-1}$ soil) (Joynt et al., 2006; Kourtev et al., 2006; Nakatsu et al., 2005). Bacteria were initially isolated from the soil on $50 \%$ tryptic soy agar (TSA) amended with $0.25 \mathrm{mM} \mathrm{Cr}(\mathrm{VI})\left(\mathrm{K}_{2} \mathrm{CrO}_{4}\right)$.

From this, sixteen isolates were further selected based on their ability to grow on at least $0.5 \mathrm{mM}$ $\mathrm{Cr}(\mathrm{VI})$. The isolates were stored in glycerol stocks at $-80^{\circ} \mathrm{C}$ until further used.

\section{Cr(VI) Reduction}

For $\mathrm{Cr}(\mathrm{VI})$ reduction experiments, isolates were grown in $25 \%$ tryptic soy broth (TSB) with $0.5 \mathrm{mM}$ or $1 \mathrm{mM} \mathrm{Cr}(\mathrm{VI})$ at $30^{\circ} \mathrm{C}$ and $225 \mathrm{rpm}$ for 72 hours. Two concentrations were used as certain isolates had relatively lower growth at $1 \mathrm{mM}$ compared to other isolates. The cultures were pelleted and $\mathrm{Cr}(\mathrm{VI})$ reduction was determined using a colorimetric assay (Henson et al., 2015; Urone, 1955).

\section{DNA Sequencing and bioinformatics}

Isolates were grown in TSB with $0.5 \mathrm{mM}$ or $2 \mathrm{mM} \mathrm{Cr}(\mathrm{VI})$ at $30^{\circ} \mathrm{C}$ and $225 \mathrm{rpm}$ for $24-72$ hours. The cultures were pelleted via centrifugation and stored at $-20^{\circ} \mathrm{C}$ until used in DNA extractions. FastDNA Spin Kits (MP Biomedical) were used to extract genomic DNA from the 
112 thawed pellets. The resulting DNA was stored at $-20^{\circ} \mathrm{C}$. The DNA from the 16 bacterial isolates

113 were sent to Cincinnati Children's Hospital Medical Center's Genetic Variation and Gene

114 Discovery Core facility for whole genome shotgun sequencing using one lane of an Illumina HiSeq

1152000 (100bp PE). The resulting raw genomic reads can be found in the National Center for

116 Biotechnology Information's (NCBI) Short Read Archives (SRA), accession number:

117 SRP120551.

118 Raw reads were evaluated for quality with FastQC

119 (https://www.bioinformatics.babraham.ac.uk/projects/fastqc/) and trimmed and quality filtered

120 with Trimmomatic (v 0.33) (Bolger et al., 2014). Sequence quality scores were low on R2

121 (assessed by FastQC), so the trimmed reads were cut (length of 70bp) and passed through another

122 quality filter (-Q33 -q 30 -p 50) with FastX toolkit (http://hannonlab.cshl.edu/fastx_toolkit/).

123 Reads for each sample were subsampled to 4 million reads (multiple subsampling depths were

124 tested) with seqtk (https://github.com/lh3/seqtk). Using multiple different read depths, MEGAhit

125 (Li et al., 2016) was used to assemble the data, which were then assessed for quality with QUAST

126 (Gurevich et al., 2013). CheckM (Parks et al., 2015) was used to examine genome completeness

127 and contamination (taxon marker Microbacterium). The resultant genomes were annotated by the

128 Department of Energy's Joint Genome Institute Integrated Microbial Genomes (IMG) system

129 (Markowitz et al., 2012) and are publicly available (see Table S1). A pangenomic analysis of 20

130 genomes (from this study and Henson et al. 2015) was conducted using the An'vio program

131 (version 3) (Eren et al., 2015) following the pangenomics workflow from Delmont and Eren 2018

132 (Delmont and Eren, 2018). The pangenomic analysis within An'vio also utilized other programs

133 like HMMER (Eddy, 2011), Prodigal (Hyatt et al., 2010), and NCBI's blastp (Altschul et al., 
134 1997). An'vio was also used to define clusters of orthologous groups (COGs) for the pangenomic

135 analysis using the command anvi-run-ncbi-cogs.

136 All 16, 16S rRNA gene sequences from the $\mathrm{Cr}(\mathrm{VI})$ isolates were downloaded from IMG.

137 These genes were used to generate a maximum likelihood phylogenetic tree in MEGA7 (Kumar

138 et al., 2016) and evolutionary history was inferred using the maximum likelihood Tamura-Nei

139 model (Tamura and Nei, 1993). Within IMG, annotations were searched for genes related to

$140 \mathrm{Cr}(\mathrm{VI})$ resistance and $\mathrm{Cr}(\mathrm{VI})$ reduction via keywords (e.g. efflux, reductase, $\mathrm{Cr}(\mathrm{VI})$ ). Annotated

$141 \mathrm{Cr}(\mathrm{VI})$ reductase genes were compared via BLASTP (one-way comparison on NCBI's website) to

142 a known Cr(VI) reducing chrR from Pseudomonas putida KT2440 (NP_746257) (Ackerley et al.,

143 2004b). Genes related to heavy metal resistance and antibiotic resistance were searched using

144 functional categories. Beta-lactam, chloramphenicol, and vancomycin resistance genes were also

145 identified using KEGG pathway KO identifiers. The COG category "Inorganic ion transport and

146 metabolism" was used to find annotated heavy metal efflux genes and metal resistance genes.

\section{Metal and antibiotic tolerance assays}

149 Bacterial isolates were grown on agar plates $(10 \% \mathrm{TSB}, 1.5 \%$ agar, and $0.5 \mathrm{mM} \mathrm{Cr}(\mathrm{VI}))$

150 at $30^{\circ} \mathrm{C}$ until colonies were visible. Colonies were then streaked onto fresh agar plates amended

151 with different concentrations of heavy metals (Cd 0-5 mM, Co 0-5 mM, Cr 0-20 mM, Cu 0-1 mM,

152 Ni 0-15 mM, and Zn 0-1 mM). Duplicate plates were incubated at $30^{\circ} \mathrm{C}$ for 14 days and growth

153 was confirmed by the presence of visible colonies. All bacterial isolates were plated on each metal

154 concentration in duplicate.

155 The Minimum Inhibitory Concentration (MIC) for ampicillin, chloramphenicol, and

156 vancomycin was tested on each isolate using MIC test strips (Liofilchem $\left.{ }^{\circledR}\right)$. To do this, each of 
157 the sixteen Microbacterium spp. isolates was streaked onto agar plates (50\% TSB and $1.5 \%$ agar)

158 with $0.5 \mathrm{mM} \mathrm{Cr}$ and incubated at $30^{\circ} \mathrm{C}$ for five days. Next, each isolate was suspended in a $0.85 \%$

159 sterile saline solution until it reached a density that approximated the 0.5 McFarland Turbidity

160 Standard. The isolates were then spread uniformly on a Mueller-Hinton agar plate. A MIC test

161 strip was placed in the center of each plate. The plates were incubated at $30^{\circ} \mathrm{C}$ for 24 hours. After

162 the 24 hours, the plates were removed and the MIC of each isolate to each antibiotic was

163 determined by visually documenting the zones of inhibition.

\section{Results and Discussion}

\section{Isolation of $\mathrm{Cr}(\mathrm{VI})$ reducing bacteria}

167 Though originally isolated and studied for their ability to reduce Cr(VI) (Henson et al.,

168 2015; Kourtev et al., 2009), it was speculated that these isolates may also be tolerant to other

169 contaminants, because the soils were contaminated with other heavy metals and organic solvents

170 (Joynt et al., 2006; Kourtev et al., 2006; Nakatsu et al., 2005). Among the 16 isolates studied here,

171 a wide range of $\mathrm{Cr}(\mathrm{VI})$ tolerance and reducing ability was found (Table 1). The majority (13) of

172 the isolates could tolerate $2 \mathrm{mM} \mathrm{Cr}(\mathrm{VI})$, while three of the isolates (K2B2, K36, and $\mathrm{K} 40$ ) could

173 only tolerate $0.5 \mathrm{mM} \mathrm{Cr}(\mathrm{VI})$. Interestingly, five of the 13 isolates that were able to tolerate $2 \mathrm{mM}$

$174 \mathrm{Cr}(\mathrm{VI})$ (A20, K24, K30, K33, and PF3) had observable colonies on plates containing up to 20mM

$175 \mathrm{Cr}(\mathrm{VI})$. Further, the 16 isolates also showed a wide range in $\mathrm{Cr}(\mathrm{VI})$ reduction (0-88.8\%) over a

176 72-hour incubation (Table 1). Only two isolates, K27 and K33, reduced over 80\% of the $\mathrm{Cr}(\mathrm{VI})$

177 in the experiment. Interestingly, $\mathrm{K} 27$ reduced $83 \%$ of the $\mathrm{Cr}(\mathrm{VI})$ in liquid medium but was only

178 able to tolerate $0.5 \mathrm{mM} \mathrm{Cr}(\mathrm{VI})$ when grown on solid medium, while $\mathrm{K} 33$ tolerated up to $20 \mathrm{mM}$

$179 \mathrm{Cr}(\mathrm{IV})$ and reduced $88 \%$ of the $\mathrm{Cr}(\mathrm{IV})$ present. Two additional isolates, K31 and PF3, reduced 
180 over $50 \%$ of the $\mathrm{Cr}(\mathrm{VI})$ in the experiment. There was no statistical relationship between the ability

181 of isolates to tolerate and their ability to reduce $\mathrm{Cr}(\mathrm{VI})$.

182

\section{Genomic assembly and pangenomic analysis}

Previous research has shown $\mathrm{Cr}(\mathrm{VI})$ tolerance to be related to a resistance gene $(\operatorname{chr} A)$

185 (Cervantes and Ohtake, 1988; Cervantes et al., 1990) and/or Cr(VI) reductases (chrR and yieF;(Ackerley et al., 2004b; Barak et al., 2006; Park et al., 2000; Ramirez-Diaz et al., 2008). To gain a better understanding of the $\mathrm{Cr}(\mathrm{VI})$ tolerance of these isolates, their genomes were assembled and annotated. The isolate genomes ranged in total length from 3.31 to $4.23 \mathrm{Mb}$ and all had GC content ranging from $68-70 \% \%$ (Table 2). A genomic study of 10 Macrobacterium sp. documented similar GC ranges and genome length (Corretto et al., 2015). The assembled genomes were generally over $96.7 \%$ complete and all genomes had under $4 \%$ contamination (Table 2 ).

192 Phylogenetic analysis of the 16S rRNA gene indicated that all of the isolates belong to the genus

193 Microbacterium (Figure S1 and Table S2). Specifically, the isolates were closely related to $M$.

194 oxydans, M. maritypicum, or M. paraoxydans. Microbacterium spp. have been isolated from sites

195 contaminated with metals (Avramov et al., 2016; Bollmann et al., 2010; Corretto et al., 2015),

196 radionuclides (Nedelkova et al., 2007), and petroleum (Avramov et al., 2016; Chauhan et al., 2013;

197 Wang et al., 2014). Moreover, some environmental isolates, such as M. laevaniformans strain

198 OR221, have shown to tolerate multiple metals (Ni, Co, and Cd) (Bollmann et al., 2010). A

199 genomic analysis of the latter strain provided evidence of genes (e.g. transporter and detoxification

200 genes) that could aid the strain's ability to tolerate metals (Brown et al., 2012). Other

201 Microbacterium spp. have been known to reduce Cr(VI): Microbacterium sp. SUCR140 (Soni et 
202 al., 2014), Microbacterium sp. chr-3 (Focardi et al., 2014), and Microbacterium sp. CR-07 (Liu et 203 al., 2012).

204 The pan-genome size of the 20 isolates was 7,902 protein clusters with the core genome 205 encompassing 2,073 protein clusters (26\%) (Figure 1). The majority of the genes in the core 206 genome of the 20 isolates (36\%) were placed in the "Metabolism" COG (Figure 2). Genes in the 207 COG categories "Cellular processes and signaling" and "Information storage and processing" 208 comprised 21 and 17\%, respectively of the core genome (Figure 2). The flexible pangenome was 209 dominated by genes in the COG categories "Metabolism" and "Poorly characterized/No assigned

210 COG" (36\% for both) (Figure 2). _ Relative to the core pangenome, the flexible pangenome had 211 few genes in the COG categories "Cellular processes and signaling (21\%)" and "Information 212 storage and processing 17\%" (Figure 2). The percentage of core genes in a genome can vary from 2133 to $84 \%$ (McInerney et al., 2017). For example, the Bacillus cereus core genome is $27 \%$ of the 214 pangenome, whereas the core genome of Bacillus anthracis is 65\% (McInerney et al., 2017). An 215 analysis of 20 Microcystis sp. showed the genome was comprised of $34-49 \%$ core genes and $51 \%$ 216 66\% flexible genes (Meyer et al., 2017). A study on the genomes of 12 Prochlorococcus isolates 217 found a core genome ranging from 40-67\% (Kettler et al., 2007). The relatively large genomic 218 variability seen with the Microbacterium spp. examined here could be due to selective pressures 219 that drove to gene loss or horizontal gene transfer, which in the end enhanced the ability of the 220 isolates to survive in a contaminated sediment environment.

221 The COG categories "Inorganic ion transport and metabolism (P)" and "Self-defense 222 mechanism (V)" were examined due to their relation to heavy metal and antibiotic transport. The 223 flexible genome has relatively higher percentages of genes in both the self-defense (1\% of the core 224 genome and 3\% of the flexible genome) and inorganic ion transport and metabolism (5\% of the 
225 core genome and $6 \%$ of the flexible genome) COG category. Each of these COG categories

226 includes predicted gene functions for heavy metal transport and antimicrobial resistance and

227 antibiotic efflux/transporters (Figure 1). Interestingly, the core and flexible genomes contain

228 different $\mathrm{Co} / \mathrm{Zn} / \mathrm{Cd}$ efflux system component genes and multidrug efflux pump genes, which

229 suggest tolerance to heavy metals and antibiotics. The variability found here may be related to the

230 ability of each isolate to tolerate different types and concentration of heavy metals and antibiotics.

231

232 Genomic insights of $\mathrm{Cr}(\mathrm{VI})$ reduction

233 The annotated genomes from this study provided evidence that these isolates could reduce

$234 \mathrm{Cr}(\mathrm{VI})$. All possess annotated $\mathrm{Cr}(\mathrm{VI})$ reductase, $\operatorname{chr}$ (Table S3). In addition, M. sp K24 and K30

235 contained two annotated $c h r R$ genes. The $\mathrm{Cr}(\mathrm{VI})$ reductases were compared with a known $\mathrm{Cr}(\mathrm{VI})$

236 reductase from Pseudomonas putida KT2440 (Park et al., 2000) and BLASTP results showed that

237 all the Microbacterium spp. chrR genes shared a high degree of homology (ranging from 40-46\%

238 identity) (Table S3). Thus, it is likely that these chrR genes are responsible for the $\operatorname{Cr}(\mathrm{VI})$

239 reduction ability of these isolates. Interestingly, other Microbacterium spp. isolated from this site

240 did not have annotated $\mathrm{Cr}(\mathrm{VI})$ reductases but BLAST searches were able to identify genes

241 homologous to $c h r R$ and yeiF (Henson et al., 2015), further suggesting high interspecies genetic

242 diversity in the putative Microbacterium spp. $\mathrm{Cr}(\mathrm{VI})$ reductases found in the same soil.

$243 \mathrm{Cr}(\mathrm{VI})$ tolerance might not be related to efflux pumps and $\mathrm{Cr}(\mathrm{VI})$ reductases. While the genomes

244 did contain $\mathrm{Cr}(\mathrm{VI})$ specific reductases, they did not contain a $\mathrm{Cr}(\mathrm{VI})$ efflux pump (chrA). The lack

245 of an assembled and annotated $c h r A$ was interesting since the ability of the isolates to reduce and

246 resist $\mathrm{Cr}(\mathrm{VI})$ did not correlate. While the lack of an assembled chrA does not confirm its absence

247 from the genome, tolerance could be related to other genes. $\operatorname{Cr}(\mathrm{IV})$ tolerance has been shown to 
248 be related genes that involve oxidative stress response (Ackerley et al., 2004a; Cheng et al., 2009),

249 DNA repair (Hu et al., 2005; Miranda et al., 2005), and metabolism (Brown et al., 2006; Decorosi

250 et al., 2009; Henne et al., 2009b).

251

\section{Tolerance to multiple heavy metals and antibiotics}

253

The isolates' genomes all contained numerous genes that suggest these bacteria can tolerate

254

255

256

257

258

259

260

261

262

263

264

265

266

267

268

269

270

multiple heavy metals (e.g. Co, Zn, and Cd) and antibiotics. When examining KEGG pathways that related to transport, all of the isolates had genes that were annotated to be $\mathrm{Co} / \mathrm{Zn} / \mathrm{Cd}$ efflux system components (Table S4). In addition, some isolates had a putative cadmium resistance protein (Table S4). KEGG pathways also documented genes that could provide tolerance to three different antibiotics (ampicillin, chloramphenicol, and vancomycin) (Table S4).

The isolates' physiological ability to tolerate heavy metals were examined to determine whether the inferred resistance based on the putative metal transport genes could be confirmed. All the isolates were streaked onto plates with various concentrations of $\mathrm{Cd}, \mathrm{Co}, \mathrm{Cr}, \mathrm{Cu}, \mathrm{Ni}$, and $\mathrm{Zn}$. Overall, 11 of the 16 isolates tolerated between 0.1 to $1.0 \mathrm{mM}$ of all six tested metals (Table 1). All 16 isolates were able to tolerate $\mathrm{Cr}, \mathrm{Ni}, \mathrm{Zn}$, and $\mathrm{Cu}$ (Table 1). As the isolates were enriched with $\mathrm{Cr}$, it was expected that they would be able to tolerate higher concentrations of Cr. Overall, the bacteria isolated in this study were able to tolerate many heavy metals, a finding seen in other studies. Microbacterium spp. enriched from Ni-rich serpentine soils have been previously documented to tolerate multiple heavy metals including $\mathrm{Cd}(0.5-2.5 \mathrm{mM}), \mathrm{Co}(0.1-5 \mathrm{mM}), \mathrm{Cr}(1-5$ $\mathrm{mM}), \mathrm{Cu}(0.25-10 \mathrm{mM}), \mathrm{Ni}(5-15 \mathrm{mM})$ and $\mathrm{Zn}(5-10 \mathrm{mM})$ (Abou-Shanab et al., 2007). Another study found that multiple isolates closely related to M. oxydans were able to tolerate $\mathrm{Cu}(0.25-16$ $\mathrm{mM}), \operatorname{Cr}(0.5-16 \mathrm{mM})$, and Ni (0.25-16 mM) (Nedelkova et al., 2007). As Microbacterium spp. 
271 have been isolated from contaminated environments, it is not surprising to find they can tolerate

272 heavy metal contamination. While this study did not attempt to confirm the function of the

$273 \mathrm{Co} / \mathrm{Zn} / \mathrm{Cd}$ efflux system components found in these genomes (Table S4), the presence of these

274 genes could be related to the ability of these isolates to tolerate multiple heavy metals. Whether

275 in culture (e.g. Pseudomonas putida or Cupriavidus necator, formerly Alcaligenes eutrophus)

276 (Manara et al., 2012; Nies, 1995) or in soil microcosms (Cabral et al., 2016), cobalt-zinc-cadmium

277 efflux system proteins have been shown to provide tolerance to heavy metals. Thus, is it possible

278 that the presence of these genes plays the same role in the isolates documented in this study.

279 There is a long history of research linking metal tolerance and antibiotic resistance (e.g.

280 Baker-Austin et al., 2006; Calomiris et al., 1984; Henriques et al., 2016; Seiler and Berendonk,

281 2012). In this study, thirteen of the sixteen isolates showed tolerance to ampicillin,

282 chloramphenicol, and vancomycin (Table 3). Specifically, 13 out of 16 isolates were able to grow

283 in the presence of ampicillin with tolerances ranging from 1.5 to $16 \mu \mathrm{g} \mathrm{ml}^{-1}$ (Table 3).

284 Chloramphenicol tolerance was found in 15 out of 16 isolates, of which 4 isolates, K24, K35, K36

285 and $\mathrm{K} 5 \mathrm{D}$, tolerated $24 \mu \mathrm{g} \mathrm{ml}^{-1}$ of the antibiotic (Table 3). Microbacterium isolates have been

286 previously documented to tolerate various antibiotics. Microbacterium isolates from fish mucus

287 have shown high antibiotic resistance to both ampicillin $\left(>1600 \mu \mathrm{g} \mathrm{ml}^{-1}\right)$ and chloramphenicol (>

$288960 \mu \mathrm{g} \mathrm{ml}^{-1}$ ) (Ozaktas et al., 2012). Human isolated Microbacterium spp. have been reported to

289 grow in the presence of vancomycin in concentrations ranging from 0.25 to $15 \mu \mathrm{g} \mathrm{ml}^{-1}$ (Gneiding 290 et al., 2008). Other clinical Microbacterium isolates had MIC for ampicillin from 1 to $1.5 \mu \mathrm{g} \mathrm{ml}^{-1}$ 291 and vancomycin from 3 to $4 \mu \mathrm{g} \mathrm{ml}^{-1}$ (Laffineur et al., 2003). A 2015 study found $26 \%$ of 292 Microbacterium isolates were resistant to vancomycin (Bernard and Pacheco, 2015). 
Metal and antibiotic co-tolerance has been reported in a number of environmentally

294 isolated bacteria. Bacteria isolated from drinking water with noted antibiotic resistance were also

295 tolerant to high levels of $\mathrm{Cu}^{2+}, \mathrm{Pb}^{2+}$, and $\mathrm{Zn}^{2+}$ (Calomiris et al., 1984). Environmental isolates from

296 wastewater treatment plants have been shown to tolerate various heavy metals and antibiotics

297 (Shafique et al., 2016; 2017). Bacillus spp. isolated from river water tolerated multiple heavy

298 metals and antibiotics (Shammi and Ahmed, 2016). Co-tolerance to heavy metals, antibiotics, and

299 polychlorinated biphenyls was also observed in isolates from Antarctic sediments (Giudice et al.,

300 2013). Further, evidence of shared genetic tolerance mechanisms for metals and antibiotics was

301 found in Staphylococcus aureus isolated from a polluted riverbank. S. aureus contained a novel

302 emr $A B$ operon encoding efflux pumps that were inducible by the heavy metals $\operatorname{Cr}(\mathrm{VI})$ and

303 manganese and the antibiotics ampicillin and chloramphenicol (Zhang et al., 2016).

304 While this study does not prove function, the data suggests the antibiotic tolerances found

305 in these isolates could be related to the antibiotic resistance genes documented in the genomes.

306 For example, 15 out of 16 isolates were able to tolerate chloramphenicol matching the 15 genomes

307 that contained an annotated chloramphenicol resistance gene (cmlR, cmx) (Table S4), a gene

308 previously shown to provide Corynebacterium striatum with chloramphenicol tolerance (Schwarz

309 et al., 2004; Tauch et al., 1998). It is possible cmx could therefore provide tolerance to the

310 Microbacterium isolates. Similarly, all the Microbacterium isolates had an annotated class A beta-

311 lactamase gene (penP), a gene that provides ampicillin tolerance to numerous bacteria (Bush and

312 Jacoby, 2010), though not all isolates were resistant to ampicillin (Table 3).

313

314 Implications to community functions 
All Microbacterium spp. were isolated from the same contaminated soil and have highly

316 similar 16S rRNA genes (99-100\% BLAST identity). Yet, these isolates displayed both genomic

317 variation and varying abilities to tolerate multiple heavy metals and antibiotics. Other studies have

318 shown that closely related isolates can exhibit variable ranges of genomic and physiological

319 differences (Coleman and Chisholm, 2010; Henson et al., 2015; Hunt et al., 2008; Martiny et al.,

320 2006; Meyer and Huber, 2014; Qamar et al., 2017; Rocap et al., 2003; Simmons et al., 2008; Welch

321 et al., 2002). A study of 78 Myxococcus xanthus isolates from a small soil plot found 21 different

322 genotypes (Vos and Velicer, 2006). Thus, it is speculated that genomic and physiological diversity

323 would allow populations to differentiate, potentially increasing resistance and/or resilience that

324 would aid the community to thrive during metals and other contaminant stress. Further support for

325 this could be found when examining the $\mathrm{Cr}(\mathrm{VI})$ reduction and resistance data. While none of the

326 isolates had an annotated $\mathrm{Cr}(\mathrm{VI})$ resistance efflux pump (chrA), they all contained a $\mathrm{Cr}(\mathrm{VI})$

327 reductase $($ chrR), yet there was variability found in their ability to reduce and resist $\mathrm{Cr}(\mathrm{VI})$. As

328 the isolates from this study were from a soil with multiple contaminants, specific isolates that more

329 efficiently reduce $\mathrm{Cr}$ (VI) (making it less bioavailable) may allow other community members

330 (without resistance genes) to thrive and possibly degrade other contaminants. Thus, the variation

331 observed in these isolates could be a reflection of how the environmental stressors (e.g. heavy

332 metals) can promote genomic diversity and a more stable community.

333

\section{Acknowledgements}

335 We thank Jorge W. Santo Domingo for assistance with data analysis and helpful comments on the 336 manuscript. We also thank Amber Conley for assistance with lab work. This is contribution 337 number XX of the CMU Institute for Great Lakes Research. 


\section{References}

340 Abou-Shanab RAI, Van Berkum P, Angle JS 2007. Heavy metal resistance and genotypic analysis

341 of metal resistance genes in gram-positive and gram-negative bacteria present in Ni-rich

342 serpentine soil and in the rhizosphere of Alyssum murale. Chemosphere 68:360-367. DOI:

$343 \quad$ 10.1016/j.chemosphere.2006.12.051.

344 Ackerley DF, Gonzalez CF, Keyhan M, Blake R, Matin A 2004a. Mechanism of chromate 345 reduction by the Escherichia coli protein, NfsA, and the role of different chromate reductases

346 in minimizing oxidative stress during chromate reduction. Environ Microbiol 6:851-860.

347 DOI: $10.1111 /$ j.1462-2920.2004.00639.x.

348 Ackerley DF, Gonzalez CF, Park CH, Blake R, Keyhan A, Matin A 2004b. Chromate-reducing 349 properties of soluble Flavoproteins from Pseudomonas putida and Escherichia coli. Applied and Environmental Microbiology 70:873-882. DOI: 10.1128/Aem.70.2.873-882.2004.

351 Altschul SF, Madden TL, Schaffer AA, Zhang JH, Zhang Z, Miller W, Lipman DJ 1997. Gapped BLAST and PSI-BLAST: a new generation of protein database search programs. Nucleic acids research 25:3389-3402. DOI: 10.1093/nar/25.17.3389.

Avramov AP, Couger MB, Hartley EL, Land C, Wellendorf R, Hanafy RA, Budd C, French DP, Hoff WD, Youssef N 2016. Draft genome sequence of Microbacterium oleivorans strain Wellendorf implicates heterotrophic versatility and bioremediation potential. Genomics Data 10:54-60. DOI: 10.1016/j.gdata.2016.09.005.

Baker-Austin C, Wright MS, Stepanauskas R, McArthur JV 2006. Co-selection of antibiotic and 359 metal resistance. Trends Microbiol 14:176-182. DOI: 10.1016/j.tim.2006.02.006. 
360 Barak Y, Ackerley DF, Dodge CJ, Banwari L, Alex C, Francis AJ, Matin A 2006. Analysis of

361 novel soluble chromate and uranyl reductases and generation of an improved enzyme by

362 directed evolution. Applied and Environmental Microbiology 72:7074-7082. DOI:

363 10.1128/AEM.01334-06.

364 Bartlett RJ 1991. Chromium Cycling in Soils and Water - Links, Gaps, and Methods.

365 Environmental Health Perspectives 92:17-24.

366 Bernard K, Pacheco AL 2015. In Vitro Activity of 22 Antimicrobial Agents against

367 Corynebacterium and Microbacterium Species Referred to the Canadian National

368 Microbiology Laboratory. Clinical Microbiology Newsletter 37:187-198. DOI:

$369 \quad$ 10.1016/j.clinmicnews.2015.11.003.

370 Bolger AM, Lohse M, Usadel B 2014. Trimmomatic: a flexible trimmer for Illumina sequence 371 data. Bioinformatics 30:2114-2120.

372 Bollmann A, Palumbo AV, Lewis K, Epstein SS 2010. Isolation and Physiology of Bacteria from 373 Contaminated Subsurface Sediments. Applied and Environmental Microbiology 76:7413374 7419. DOI: 10.1128/Aem.00376-10.

375 Briand E, Escoffier N, Straub C, Sabart M, Quiblier C, Humbert J-F 2009. Spatiotemporal changes 376 in the genetic diversity of a bloom-forming Microcystis aeruginosa (cyanobacteria) population. The ISME journal 3:419-429. DOI: 10.1038/ismej.2008.121.

378 Brose DA, James BR 2010. Oxidation-Reduction Transformations of Chromium in Aerobic Soils and the Role of Electron-Shuttling Quinones. Environ Sci Technol 44:9438-9444.

380 Brown SD, Palumbo AV, Panikov N, Arlyawansa T, Klingeman DM, Johnson CM, Land ML, 381 Utturkar SM, Epstein SS 2012. Draft Genome Sequence for Microbacterium laevaniformans 

3280. DOI: $10.1128 / \mathrm{JB} .00474-12$.

384 Brown SD, Thompson MR, Verberkmoes NC, Chourey K, Shah M, Zhou J, Hettich RL,

385 Thompson DK 2006. Molecular dynamics of the Shewanella oneidensis response to chromate 386 stress. Mol Cell Proteomics 5:1054-1071. DOI: 10.1074/mcp.M500394-MCP200.

387 Bush K, Jacoby GA 2010. Updated functional classification of beta-lactamases. Antimicrobial 388 agents and chemotherapy 54:969-976. DOI: 10.1128/AAC.01009-09.

Cabral L, Júnior GVL, Pereira de Sousa ST, Dias ACF, Lira Cadete L, Andreote FD, Hess M, de 390 Oliveira VM 2016. Anthropogenic impact on mangrove sediments triggers differential 391 responses in the heavy metals and antibiotic resistomes of microbial communities. Environmental Pollution 216:460-469. DOI: 10.1016/j.envpol.2016.05.078.

393 Calomiris JJ, Armstrong JL, Seidler RJ 1984. Association of metal tolerance with multiple 394 antibiotic resistance of bacteria isolated from drinking water. Applied and Environmental 395 Microbiology 47:1238-1242.

396 Cervantes C, Ohtake H 1988. Plasmid-determined resistance to chromate in Pseudomonas 397 aeruginosa. FEMS Microbiology Letters 56:173-176.

398 Cervantes C, Ohtake H, Chu L, Misra TK, Silver S 1990. Cloning, nucleotide sequence, and 399 expression of the chromate resistance determinant of Pseudomonas aeruginosa plasmid 400

Chauhan A, Green S, Pathak A, Thomas J, Venkatramanan R 2013. Whole-Genome Sequences of pUM505. Journal of Bacteriology 172:287-291. 
404 Cheng Y, Holman H-Y, Lin Z 2012. Remediation of Chromium and Uranium Contamination by $405 \quad$ Microbial Activity. Elements 8:107-112.

406 Cheng Y, XIE Y, ZHENG J, WU Z, CHEN Z, MA X, LI B, Lin Z 2009. Identification and 407 characterization of the chromium(VI) responding protein from a newly isolated Ochrobactrum 408 anthropi CTS-325. Journal of Environmental Sciences-China 21:1673-1678. DOI: $409 \quad$ 10.1016/S1001-0742(08)62472-9.

410 Cheung KH, Gu JD 2007. Mechanism of hexavalent chromium detoxification by microorganisms 411 and bioremediation application potential: A review. International Biodeterioration \& 412 Biodegradation 59:8-15. DOI: 10.1016/j.ibiod.2006.05.002.

413 Coleman ML, Chisholm SW 2010. Ecosystem-specific selection pressures revealed through 414 comparative population genomics. Proceedings of the National Academy of Sciences of the $415 \quad$ United States of America 107:18634-18639. DOI: 10.1073/pnas.1009480107.

416 Corretto E, Antonielli L, Sessitsch A, Kidd P, Weyens N, Brader G 2015. Draft Genome Sequences 417 of 10 Microbacterium spp., with Emphasis on Heavy Metal-Contaminated Environments. Genome Announcements 3:e00432-15. DOI: 10.1128/genomeA.00432-15.

419 Decorosi F, Tatti E, Mini A, Giovannetti L, Viti C 2009. Characterization of two genes involved 420 in chromate resistance in a $\mathrm{Cr}(\mathrm{VI})$-hyper-resistant bacterium. Extremophiles : life under 421 extreme conditions 13:917-923. DOI: 10.1007/S00792-009-0279-6.

422 Delmont TO, Eren AM 2018. Linking pangenomes and metagenomes: the Prochlorococcus 423 metapangenome. Peerj 6:e4320. DOI: 10.7717/peerj.4320.

424 Denef VJ, Kalnejais LH, Mueller RS, Wilmes P, Baker BJ, Thomas BC, VerBerkmoes NC, Hettich 425 RL, Banfield JF 2010. Proteogenomic basis for ecological divergence of closely related 426 bacteria in natural acidophilic microbial communities. Proceedings of the National Academy 
of Sciences of the United States of America 107:200907041-2390. DOI:

10.1073/pnas.0907041107.

429 Eddy SR 2011. Accelerated Profile HMM Searches. 7:e1002195. DOI: $430 \quad$ 10.1371/journal.pcbi.1002195.

431 Eren AM, Esen OC, Quince C, Vineis JH, Morrison HG, Sogin ML, Delmont TO 2015. Anvi“"o: 432 an advanced analysis and visualization platform for "omics data. Peerj 3:e1319. DOI: $433 \quad 10.7717 /$ peerj.1319.

434 Focardi S, Pepi M, Focardi SE 2014. Microbial Reduction of Hexavalent Chromium as a 435 Mechanism of Detoxification and Possible Bioremediation Applications. In: Chamy R, 436 Rosenkranz F eds. Biodegradation - Life of Science. InTech. DOI: 10.5772/56365.

437 Frangeul L, Quillardet P, Castets A-M, Humbert J-F, Matthijs HC, Cortez D, Tolonen A, Zhang 438 C-C, Gribaldo S, Kehr J-C, Zilliges Y, Ziemert N, Becker S, Talla E, Latifi A, Billault A, 439 Lepelletier A, Dittmann E, Bouchier C, de Marsac NT 2008. Highly plastic genome of 440 Microcystis aeruginosa PCC 7806, a ubiquitous toxic freshwater cyanobacterium. BMC Genomics 9:274. DOI: 10.1186/1471-2164-9-274.

442 Ghosh A, Singh A, Ramteke PW, Singh VP 2000. Characterization of Large Plasmids Encoding 443 Resistance to Toxic Heavy Metals in Salmonella abortus equi. Biochemical and Biophysical $444 \quad$ Research Communications 272:6-11. DOI: 10.1006/bbrc.2000.2727.

445 Giudice Lo A, Casella P, Bruni V, Michaud L 2013. Response of bacterial isolates from Antarctic 446 shallow sediments towards heavy metals, antibiotics and polychlorinated biphenyls. 447 Ecotoxicology 22:240-250. DOI: 10.1007/S10646-012-1020-2. 
448 Gneiding K, Frodl R, Funke G 2008. Identities of Microbacterium spp. encountered in human 449 clinical specimens. Journal of Clinical Microbiology 46:3646-3652. DOI: 10.1128/JCM.01202-08.

451 Gonzalez CF, Ackerley DF, Lynch SV, Matin A 2005. ChrR, a soluble quinone reductase of 452 Pseudomonas putida that defends against H2O2. Journal of Biological Chemistry 280:22590453 22595. DOI: 10.1074/jbc.M501654200.

454 Gurevich A, Saveliev V, Vyahhi N, Tesler G 2013. QUAST: quality assessment tool for genome assemblies. Bioinformatics 29:1072-1075.

Henne KL, Nakatsu CH, Thompson DK, Konopka AE 2009a. High-level chromate resistance in Arthrobacter sp. strain FB24 requires previously uncharacterized accessory genes. BMC Microbiology 9:199. DOI: 10.1186/1471-2180-9-199.

Henne KL, Turse JE, Nicora CD, Lipton MS, Tollaksen SL, Lindberg C, Babnigg G, Giometti CS, Nakatsu CH, Thompson DK, Konopka AE 2009b. Global Proteomic Analysis of the Chromate Response in Arthrobacter sp. Strain FB24. Journal of Proteome Research 8:1704-1716. DOI:

Henriques I, Tacão M, Leite L, Fidalgo C, Araújo S, Oliveira C, Alves A 2016. Co-selection of 464 antibiotic and metal(loid) resistance in gram-negative epiphytic bacteria from contaminated salt marshes. Marine pollution bulletin 109:427-434. DOI: 10.1016/j.marpolbul.2016.05.031.

466 Henson MW, Santo Domingo JW, Kourtev PS, Jensen RV, Dunn JA, Learman DR 2015. 467 Metabolic and genomic analysis elucidates strain-level variation in Microbacterium spp. 468 isolated from chromate contaminated sediment. Peerj 3:e1395. DOI: 10.7717/peerj.1395. 
469 Hu P, Brodie EL, Suzuki Y, McAdams HH, Andersen GL 2005. Whole-Genome Transcriptional 470 Analysis of Heavy Metal Stresses in Caulobacter crescentus. J Bacteriol 187:8437-8449. DOI: $10.1128 / J B .187 .24 .8437-8449.2005$.

472 Humbert J-F, Barbe V, Latifi A, Gugger M, Calteau A, Coursin T, Lajus A, Castelli V, Oztas S, 473 Samson G, Longin C, Medigue C, de Marsac NT 2013. A Tribute to Disorder in the Genome 474 of the Bloom-Forming Freshwater Cyanobacterium Microcystis aeruginosa. Plos One 8:e70747. DOI: 10.1371/journal.pone.0070747.

Humphries AC, Nott KP, Hall LD, Macaskie LE 2005. Reduction of Cr(VI) by immobilized cells of Desulfovibrio vulgaris NCIMB 8303 and Microbacterium sp. NCIMB 13776. Biotechnology and Bioengineering 90:589-596. DOI: 10.1002/bit.20450.

Hunt DE, David LA, Gevers D, Preheim SP, Alm EJ, Polz MF 2008. Resource partitioning and sympatric differentiation among closely related bacterioplankton. Science 320:1081-1085. DOI: $10.1126 /$ Science. 1157890 .

Hyatt D, Chen GL, Locascio PF, Land ML, Larimer FW, Hauser LJ 2010. Prodigal: prokaryotic gene recognition and translation initiation site identification. BMC bioinformatics 11:119. DOI: $10.1186 / 1471-2105-11-119$.

Joynt J, Bischoff M, Turco R, Konopka A, Nakatsu CH 2006. Microbial community analysis of soils contaminated with lead, chromium and petroleum hydrocarbons. Microbial Ecology 51:209-219. DOI: 10.1007/s00248-005-0205-0.

Kettler GC, Martiny AC, Huang K, Zucker J, Coleman ML, Rodrigue S, Chen F, Lapidus A, 489 Ferriera S, Johnson J, Steglich C, Church GM, Richardson P, Chisholm SW 2007. Patterns 490 and Implications of Gene Gain and Loss in the Evolution of Prochlorococcus. PLOS Genetics 491 3:e231. DOI: 10.1371/journal.pgen.0030231. 
492 Kourtev PS, Nakatsu CH, Konopka A 2006. Responses of the anaerobic bacterial community to 493 addition of organic $\mathrm{C}$ in chromium(VI)- and iron(III)-amended microcosms. Applied and 494 Environmental Microbiology 72:628-637. DOI: 10.1128/Aem.72.1.628-637.2006.

495 Kourtev PS, Nakatsu CH, Konopka A 2009. Inhibition of nitrate reduction by chromium(VI) in 496 anaerobic soil microcosms. Applied and Environmental Microbiology.

497 Kumar S, Stecher G, Tamura K 2016. MEGA7: Molecular Evolutionary Genetics Analysis 498 Version 7.0 for Bigger Datasets. Molecular biology and evolution 33:1870-1874. DOI: $499 \quad 10.1093 / \mathrm{molbev} / \mathrm{msw} 054$.

500 Laffineur K, Avesani V, Cornu G, Charlier J, Janssens M, Wauters G, Delmée M 2003. Bacteremia 501 due to a novel Microbacterium species in a patient with leukemia and description of 502 Microbacterium paraoxydans sp. nov. Journal of Clinical Microbiology 41:2242-2246. DOI: 503 10.1128/JCM.41.5.2242-2246.2003.

504 Li DH, Luo RB, Liu CM, Leung CM, Ting HF, Sadakane K, Yamashita H, Lam TW 2016. 505 MEGAHIT v1.0: A fast and scalable metagenome assembler driven by advanced 506 methodologies and community practices. Methods 102:3-11.

507 Liu ZM, Wu Y, Lei CF, Liu PM, Gao MY 2012. Chromate reduction by a chromate-resistant 508 bacterium, Microbacterium sp. World Journal of Microbiology \& Biotechnology 28:1585509 1592. DOI: $10.1007 / \mathrm{s} 11274-011-0962-5$.

510 Manara A, DalCorso G, Baliardini C, Farinati S, Cecconi D, Furini A 2012. Pseudomonas putida

511 Response to Cadmium: Changes in Membrane and Cytosolic Proteomes. Journal of Proteome 512 Research 11:4169-4179. DOI: 10.1021/pr300281f.

513 Markowitz VM, Chen IMA, Palaniappan K, Chu K, Szeto E, Grechkin Y, Ratner A, Jacob B, 514 Huang JH, Williams P, Huntemann M, Anderson I, Mavromatis K, Ivanova NN, Kyrpides NC 
515

516

517

518

519

520

521

522

523

524

525

526

527

528

529

530

531

532

533

534

535

536

537

2012. IMG: the integrated microbial genomes database and comparative analysis system. Nucleic acids research 40:D115-D122. DOI: 10.1093/Nar/Gkr1044.

Martiny AC, Coleman ML, Chisholm SW 2006. Phosphate acquisition genes in Prochlorococcus ecotypes: Evidence for genome-wide adaptation. Proceedings of the National Academy of Sciences of the United States of America 103:12552-12557. DOI: 10.1073/pnas.0601301103.

McInerney JO, McNally A, O'Connell MJ 2017. Why prokaryotes have pangenomes. Nature Microbiology 2:17040. DOI: 10.1038/nmicrobiol.2017.40.

Meyer JL, Huber JA 2014. Strain-level genomic variation in natural populations of Lebetimonas from an erupting deep-sea volcano. The ISME journal 8:867-880. DOI: 10.1038/ismej.2013.206.

Meyer KA, Davis TW, Watson SB, Denef VJ, Berry MA, Dick GJ 2017. Genome sequences of lower Great Lakes Microcystis sp. reveal strain-specific genes that are present and expressed in western Lake Erie blooms. Plos One 12:e0183859. DOI: 10.1371/journal.pone.0183859.

Miranda AT, González MV, González G, Vargas E, Campos-Garcia J, Cervantes C 2005. Involvement of DNA helicases in chromate resistance by Pseudomonas aeruginosa PAO1. Mutation research 578:202-209. DOI: 10.1016/j.mrfmmm.2005.05.018.

Nakatsu CH, Carmosini N, Baldwin B, Beasley F, Kourtev P, Konopka A 2005. Soil microbial community responses to additions of organic carbon substrates and heavy metals $(\mathrm{Pb}$ and $\mathrm{Cr})$. Applied and Environmental Microbiology 71:7679-7689. DOI: 10.1128/Aem.71.12.76797689.2005

Nedelkova M, Merroun ML, Rossberg A, Hennig C, Pobell SS 2007. Microbacterium isolates from the vicinity of a radioactive waste depository and their interactions with uranium. Fems Microbiology Ecology 59:694-705. DOI: 10.1111/j.1574-6941.2006.00261.x. 
538 Nies A, Nies DH, Silver S 1990. Nucleotide sequence and expression of a plasmid-encoded 539 chromate resistance determinant from Alcaligenes eutrophus. Journal of Biological Chemistry $540 \quad 265: 5648-5653$.

541 Nies DH 1995. The cobalt, zinc, and cadmium efflux system CzcABC from Alcaligenes eutrophus 542 functions as a cation-proton antiporter in Escherichia coli. J Bacteriol 177:2707-2712. DOI: $10.1128 / \mathrm{jb} .177 .10 .2707-2712.1995$.

544 Nies DH 2003. Efflux-mediated heavy metal resistance in prokaryotes. FEMS Microbiology Reviews 27:313-339. DOI: 10.1016/S0168-6445(03)00048-2.

546 Niewerth H, Schuldes J, Parschat K, Kiefer P, Vorholt JA, Daniel R, Fetzner S 2012. Complete 547 genome sequence and metabolic potential of the quinaldine-degrading bacterium Arthrobacter sp. Rue61a. BMC Genomics 13. DOI: 10.1186/1471-2164-13-534.

Opperman DJ, Piater LA, van Heerden E 2008. A novel chromate reductase from Thermus scotoductus SA-01 related to old yellow enzyme. J Bacteriol 190:3076-3082. DOI: 10.1128/Jb.01766-07.

Ozaktas T, Taskin B, Gozen AG 2012. High level multiple antibiotic resistance among fish surface associated bacterial populations in non-aquaculture freshwater environment. Water Research

Oze C, Fendorf S, Bird DK, Coleman RG 2004. Chromium geochemistry in serpentinized 556 ultramafic rocks and serpentine soils from the Franciscan Complex of California. American Journal of Science 304:67-101.

Park CH, Keyhan M, Wielinga B, Fendorf S, Matin A 2000. Purification to Homogeneity and Characterization of a Novel Pseudomonas putida Chromate Reductase. Applied and Environmental Microbiology 66:1788-1795. DOI: 10.1128/aem.66.5.1788-1795.2000. 
561 Parks DH, Imelfort M, Skennerton CT, Hugenholtz P, Tyson GW 2015. CheckM: assessing the

562 quality of microbial genomes recovered from isolates, single cells, and metagenomes. Genome

563 Res 25:1043-1055. DOI: 10.1101/gr.186072.114.

564 Pattanapipitpaisal P, Brown NL, Macaskie LE 2001. Chromate reduction by Microbacterium

565 liquefaciens immobilised in polyvinyl alcohol. Biotechnology Letters 23:61-65. DOI:

$566 \quad 10.1023 / \mathrm{A}: 1026750810580$.

567 Qamar N, Rehman Y, Hasnain S 2017. Arsenic-resistant and plant growth-promoting Firmicutes

568 and $\gamma$-Proteobacteria species from industrially polluted irrigation water and corresponding 569 cropland. Journal of Applied Microbiology 123:748-758. DOI: 10.1111/jam.13535.

570 Ramirez-Diaz MI, Diaz-Perez C, Vargas E, Riveros-Rosas H, Campos-Garcia J, Cervantes C

571 2008. Mechanisms of bacterial resistance to chromium compounds. Biometals 21:321-332.

$572 \quad$ DOI: $10.1007 / \mathrm{s} 10534-007-9121-8$.

573 Rocap G, Larimer FW, Lamerdin J, Malfatti S, Chain P, Ahlgren NA, Arellano A, Coleman M, 574 Hauser L, Hess WR, Johnson ZI, Land M, Lindell D, Post AF, Regala W, Shah M, Shaw SL, 575 Steglich C, Sullivan MB, Ting CS, Tolonen A, Webb EA, Zinser ER, Chisholm SW 2003. 576 Genome divergence in two Prochlorococcus ecotypes reflects oceanic niche differentiation. Nature 424:1042-1047. DOI: 10.1038/Nature01947.

578 Schwarz S, Kehrenberg C, Doublet B, Cloeckaert A 2004. Molecular basis of bacterial resistance 579 to chloramphenicol and florfenicol. FEMS Microbiology Reviews 28:519-542. DOI: $580 \quad$ 10.1016/j.femsre.2004.04.001.

581 Seiler C, Berendonk TU 2012. Heavy metal driven co-selection of antibiotic resistance in soil and 582 water bodies impacted by agriculture and aquaculture. Frontiers in Microbiology 3:399. DOI: $583 \quad 10.3389 /$ fmicb.2012.00399. 
584 Shafique M, Jawaid A, Rehman Y 2016. As(V) Reduction, As(III) Oxidation, and Cr(VI)

585 Reduction by Multi-metal-resistant Bacillus subtilis, Bacillus safensis, and Bacillus cereus

586 Species Isolated from Wastewater Treatment Plant. Geomicrobiology Journal 34:687-694.

$587 \quad$ DOI: $10.1080 / 01490451.2016 .1240265$.

588 Shafique M, Jawaid A, Rehman Y 2017. Redox biotransformation of arsenic along with plant 589 growth promotion by multi-metal resistance Pseudomonas sp. MX6. Comptes Rendus $590 \quad$ Biologies 340:330-338. DOI: 10.1016/j.crvi.2017.05.002.

591 Shammi T, Ahmed S 2016. Heavy Metal Tolerance and Antibiotic Resistance of Bacillus spp. 592 Isolated from Two Major Rivers in Bangladesh. Bangladesh Journal of Microbiology 30:1722. DOI: 10.3329/bjm.v30i1-2.28448.

Silver S 1996. Bacterial resistances to toxic metal ions - A review. Gene 179:9-19. DOI: 10.1016/S0378-1119(96)00323-X.

Simmons SL, DiBartolo G, Denef VJ, Goltsman DSA, Thelen MP, Banfield JF 2008. Population Genomic Analysis of Strain Variation in Leptospirillum Group II Bacteria Involved in Acid Mine Drainage Formation. PLoS Biol 6:e177. DOI: 10.1371/journal.pbio.0060177.

Soni SK, Singh R, Awasthi A, Kalra A 2014. A Cr(VI)-reducingMicrobacteriumsp. strain SUCR140 enhances growth and yield of Zea mays in Cr(VI) amended soil through reduced chromium toxicity and improves colonization of arbuscular mycorrhizal fungi. Environmental Science and Pollution Research 21:1971-1979. DOI: 10.1007/s11356-013-2098-7.

603 Tamura K, Nei M 1993. Estimation of the number of nucleotide substitutions in the control region 604 of mitochondrial DNA in humans and chimpanzees. Molecular biology and evolution 10:512605 526. DOI: 10.1093/oxfordjournals.molbev.a040023. 
606 Tauch A, Zheng Z, Pühler A, Kalinowski J 1998. Corynebacterium striatum Chloramphenicol 607 Resistance Transposon Tn5564:Genetic Organization and Transposition in Corynebacterium 608 glutamicum. Plasmid 40:126-139. DOI: 10.1006/plas.1998.1362.

609 Ug A, Ceylan Ö 2003. Occurrence of Resistance to Antibiotics, Metals, and Plasmids in Clinical 610 Strains of Staphylococcus spp. Archives of Medical Research 34:130-136. DOI: $611 \quad 10.1016 / \mathrm{S} 0188-4409(03) 00006-7$.

612 Urone PF 1955. Stability of colorimetric reagent for chromium, s-Diphenylcarbazide, in various 613 solvents. Division of Industrial Hygiene 27.

614 Viti C, Marchi E, Decorosi F, Giovannetti L 2013. Molecular mechanisms of Cr(VI) resistance in 615 bacteria and fungi. FEMS Microbiology Reviews 38:633-659. DOI: 10.1111/1574$616 \quad 6976.12051$.

617 Vos M, Velicer GJ 2006. Genetic population structure of the soil bacterium Myxococcus xanthus 618 at the centimeter scale. Applied and Environmental Microbiology 72:3615-3625. DOI: 10.1128/AEM.72.5.3615-3625.2006.

620 Wang H, Xiang T, Wang Y, Song J, Zhai Y, Chen X, Li Y, Zhao B, Bin Zhao, Ruan Z 2014. 621 Microbacterium petrolearium sp. nov., isolated from an oil-contaminated water sample. International Journal of Systematic and Evolutionary Microbiology 64:4168-4172. DOI: 10.1099/ijs.0.061119-0.

624 Welch RA, Burland V, Plunkett G, Redford P, Roesch P, Rasko D, Buckles EL, Liou SR, Boutin 625 HLT, Donnenberg MS, Blattner FR 2002. Extensive mosaic structure revealed by the complete genome sequence of uropathogenic Escherichia coli. Proceedings of the National Academy of Sciences of the United States of America 99:17020-17024. DOI: 10.1073/pnas.252529799. 
629 Wright MS, Peltier GL, Stepanauskas R, McArthur JV 2006. Bacterial tolerances to metals and 630 antibiotics in metal-contaminated and reference streams. Fems Microbiology Ecology 58:293631 302. DOI: 10.1111/j.1574-6941.2006.00154.x.

632 Zhang H, Ma Y, Liu P, Li X 2016. Multidrug resistance operon emrAB contributes for chromate 633 and ampicillin co-resistance in a Staphylococcus strain isolated from refinery polluted river 634 bank. SpringerPlus 5:1648. DOI: 10.1186/s40064-016-3253-7.

635

636 Figure Legends

637 Figure 1. Pangenomic analysis of heavy metal tolerant Microbacterium spp. The figure was made 638 in An'vio with the items order in presence/absence (D: Euclidean; L: Ward) and the samples 639 ordered by PC frequency. The outer most complete ring (labeled Num cont.) represents the 640 number of genomes that a gene occurs in, with the core genome highlighted with an additional 641 black bar. The internal rings represent an isolate's genome with the black color representing the 642 presence of genes in a genome (gray is the absence of a gene). The bar charts shows quality control 643 measurements (total genome length [base pairs], GC content, and percent completion) and also the 644 abundance of genes that were annotated as $\mathrm{Co}, \mathrm{Zn}, \mathrm{Cd}$ efflux system genes and antibiotic tolerance 645 genes (beta lactam, vancomycin and chloramphenicol resistance).

647 Figure 2. COG distribution of genes found in the core and flexible genomes of 20 Microbacterium 648 isolates isolated from heavy metal contaminated soil.

649

650 Figure S1. Molecular Phylogenetic analysis by Maximum Likelihood method. The tree with the 651 highest log likelihood is shown. Initial tree(s) for the heuristic search were obtained automatically 
652 by applying Neighbor-Join and BioNJ algorithms to a matrix of pairwise distances estimated using 653 the Maximum Composite Likelihood (MCL) approach, and then selecting the topology with 654 superior log likelihood value. The tree is drawn to scale, with branch lengths measured in the 655 number of substitutions per site. All positions containing gaps and missing data were eliminated. 656 There were a total of 1181 positions in the final dataset. 


\section{Table $\mathbf{1}$ (on next page)}

Heavy metal tolerance and chromate reduction.

Heavy metal (cadmium, chromium, cobalt, copper, nickel, and zinc) tolerance (in mM) of each isolate and chromate reduction (\%) data. 
1 Table 1. Heavy metal tolerance and chromate reduction

\begin{tabular}{lccccccc} 
& \multicolumn{7}{c}{ Metal Tolerance (mM) } \\
\cline { 2 - 6 } Isolate & Cr & Ni & Co & Cd & Zn & Cu & $\begin{array}{c}\text { Cr reduction } \\
\text { (\%) }\end{array}$ \\
\hline Microbacterium sp. A20 & 20.0 & 1.0 & 0.1 & 0.1 & 1.0 & 1.0 & 41.6 \\
Microbacterium sp. K19 & 2.0 & 1.0 & 0.1 & 0.1 & 1.0 & 1.0 & 34.0 \\
Microbacterium sp. K21 & 2.0 & 1.0 & 0.1 & 0.1 & 1.0 & 1.0 & 39.3 \\
Microbacterium sp. K22 & 2.0 & 1.0 & 0.1 & 0.1 & 0.1 & 1.0 & 42.9 \\
Microbacterium sp. K24 & 20.0 & 1.0 & 1.0 & 0.0 & 1.0 & 1.0 & 41.6 \\
Microbacterium sp. K27 & 2.0 & 1.0 & 1.0 & 0.1 & 0.1 & 1.0 & 83.0 \\
Microbacterium sp. K2B2 & 0.5 & 0.1 & 0.0 & 0.1 & 0.1 & 0.1 & 36.0 \\
Microbacterium sp. K30 & 20.0 & 1.0 & 1.0 & 0.1 & 1.0 & 1.0 & 41.6 \\
Microbacterium sp. K31 & 2.0 & 0.1 & 0.1 & 0.1 & 1.0 & 1.0 & 55.3 \\
Microbacterium sp. K33 & 20.0 & 1.0 & 0.1 & 0.1 & 1.0 & 1.0 & 88.8 \\
Microbacterium sp. K35 & 2.0 & 0.1 & 0.1 & 0.1 & 0.1 & 1.0 & 3.6 \\
Microbacterium sp. K36 & 0.5 & 1.0 & 0.1 & 0.1 & 0.1 & 1.0 & 10.7 \\
Microbacterium sp. K40 & 0.5 & 1.0 & 0.1 & 0.1 & 1.0 & 1.0 & 30.3 \\
Microbacterium sp. K41 & 2.0 & 1.0 & 0.1 & 0.0 & 0.1 & 1.0 & 28.1 \\
Microbacterium sp. K5D & 2.0 & 1.0 & 0.1 & 0.0 & 0.1 & 1.0 & 0.0 \\
Microbacterium sp. PF3 & 20.0 & 1.0 & 0.1 & 0.0 & 1.0 & 1.0 & 50.6 \\
\hline
\end{tabular}

*Reduction \% after 72 hours with $1 \mathrm{mM}$ Cr except for K19, 31, 27 which was $0.5 \mathrm{mM}$. Data shown in percentages since two chromate concentrations were used 


\section{Table 2 (on next page)}

Assembly statistics and quality assurance data

Genome assembly statistics (total length, GC\%, and number of contigs) and quality assurance data (completeness, contamination, and strain heterogeneity). 
1 Table 2. Assembly statistics and quality assurance data

\begin{tabular}{|c|c|c|c|c|c|c|c|c|c|}
\hline Isolate & $\begin{array}{c}\text { Total } \\
\text { length } \\
\text { (Mb) } \\
\end{array}$ & $\begin{array}{l}\text { GC } \\
(\%) \\
\end{array}$ & $\begin{array}{c}\text { Number } \\
\text { of } \\
\text { contigs } \\
\end{array}$ & $\begin{array}{c}\text { Largest } \\
\text { contig } \\
\text { (bp) } \\
\end{array}$ & $\begin{array}{l}\text { N50 } \\
\text { (bp) }\end{array}$ & $\begin{array}{c}\text { Est. } \\
\text { Sequencing } \\
\text { Coverage } \\
\end{array}$ & $\begin{array}{c}\text { Comp. } \\
(\%)\end{array}$ & $\begin{array}{c}\text { Cont. } \\
(\%) \\
\end{array}$ & $\begin{array}{c}\text { Strain } \\
\text { heterogeneity } \\
(\%) \\
\end{array}$ \\
\hline Microbacterium sp. A20 & 3.94 & 68.53 & 75 & 436954 & 166569 & 142 & 99.06 & 0.54 & 0 \\
\hline Microbacterium sp. K19 & 3.89 & 68.69 & 54 & 479964 & 187157 & 144 & 99.44 & 1.01 & 20 \\
\hline Microbacterium sp. K21 & 3.85 & 68.33 & 34 & 537739 & 330631 & 146 & 99.06 & 0.18 & 0 \\
\hline Microbacterium sp. K22 & 3.94 & 68.52 & 96 & 258133 & 83317 & 142 & 99.06 & 0.71 & 33.33 \\
\hline Microbacterium sp. K24 & 4.23 & 68.90 & 142 & 248507 & 56118 & 132 & 99.35 & 3.93 & 9.09 \\
\hline Microbacterium sp. K27 & 3.75 & 68.51 & 37 & 342064 & 187856 & 149 & 98.66 & 0.18 & 0 \\
\hline Microbacterium sp. K2B2 & 3.94 & 68.52 & 76 & 436909 & 120725 & 142 & 99.06 & 0.54 & 0 \\
\hline Microbacterium sp. K30 & 4.06 & 69.16 & 96 & 295140 & 88745 & 138 & 98.39 & 2.61 & 0 \\
\hline Microbacterium sp. K31 & 3.77 & 68.43 & 39 & 443452 & 183886 & 148 & 98.66 & 0.18 & 0 \\
\hline Microbacterium sp. K33 & 3.89 & 68.68 & 110 & 311089 & 66684 & 144 & 99.44 & 1.49 & 0 \\
\hline Microbacterium sp. K35 & 3.62 & 70.91 & 379 & 168068 & 17080 & 155 & 96.70 & 1.82 & 12.5 \\
\hline Microbacterium sp. K36 & 3.31 & 70.53 & 91 & 183861 & 73738 & 169 & 98.10 & 0.60 & 0 \\
\hline Microbacterium sp. K40 & 3.77 & 68.40 & 45 & 442332 & 195355 & 148 & 99.06 & 0.09 & 0 \\
\hline Microbacterium sp. K41 & 3.62 & 70.75 & 454 & 89969 & 15114 & 155 & 97.62 & 1.37 & 0 \\
\hline Microbacterium sp. K5D & 3.80 & 68.35 & 49 & 442284 & 195368 & 147 & 99.06 & 0.09 & 0 \\
\hline Microbacterium sp. PF5 & 3.74 & 70.80 & 144 & 125065 & 47267 & 150 & 97.23 & 1.82 & 0 \\
\hline
\end{tabular}

2 


\section{Table 3(on next page)}

\section{Antibiotic Minimum Inhibitory concentrations}

Minimum inhibitory concentrations $(\mu \mathrm{g} / \mathrm{ml})$ of ampicillin, chloramphenicol, and vancomycin for each isolate. 


\section{Table 3. Minimum Inhibitory concentrations $\left(\mu \mathrm{g} \mathrm{ml}^{-1}\right)$}

\begin{tabular}{lccc} 
Isolates & Amp* & Cam* & Van* \\
\hline Microbacterium sp. A20 & 0.0 & 8.0 & 0.5 \\
Microbacterium sp. K19 & 3.0 & 12.0 & 3.0 \\
Microbacterium sp. K21 & 3.0 & 12.0 & 4.0 \\
Microbacterium sp. K22 & 1.5 & 1.5 & 1.0 \\
Microbacterium sp. K24 & 3.0 & 24.0 & 6.0 \\
Microbacterium sp. K27 & 0.0 & 12.0 & 4.0 \\
Microbacterium sp. K2B2 & 0.0 & 0.0 & 4.0 \\
Microbacterium sp. K30 & 3.0 & 16.0 & 3.0 \\
Microbacterium sp. K31 & 2.0 & 8.0 & 4.0 \\
Microbacterium sp. K33 & 2.0 & 16.0 & 3.0 \\
Microbacterium sp. K35 & 2.0 & 24.0 & 1.5 \\
Microbacterium sp. K36 & 3.0 & 24.0 & 1.5 \\
Microbacterium sp. K40 & 3.0 & 12.0 & 3.0 \\
Microbacterium sp. K41 & 1.0 & 1.5 & 1.5 \\
Microbacterium sp. K5D & 1.0 & 24.0 & 4.0 \\
Microbacterium sp. PF3 & 16.0 & 6.0 & 0.1 \\
\hline
\end{tabular}

*ampicillin (Amp), chloramphenicol (Cam), and vancomycin (Van) 


\section{Figure 1}

Pangenomic analysis of heavy metal tolerant Microbacterium spp.

The figure was made in An'vio with the items order in presence/absence (D: Euclidean; L: Ward) and the samples ordered by PC frequency. The outer most complete ring (labeled Num cont.) represents the number of genomes that a gene occurs in, with the core genome highlighted with an additional black bar. The internal rings represent an isolate's genome with the black color representing the presence of genes in a genome (gray is the absence of a gene). The bar charts shows quality control measurements (total genome length [base pairs], GC content, and percent completion) and also the abundance of genes that were annotated as Co, Zn, Cd efflux system genes and antibiotic tolerance genes (beta lactam, vancomycin and chloramphenicol resistance). 


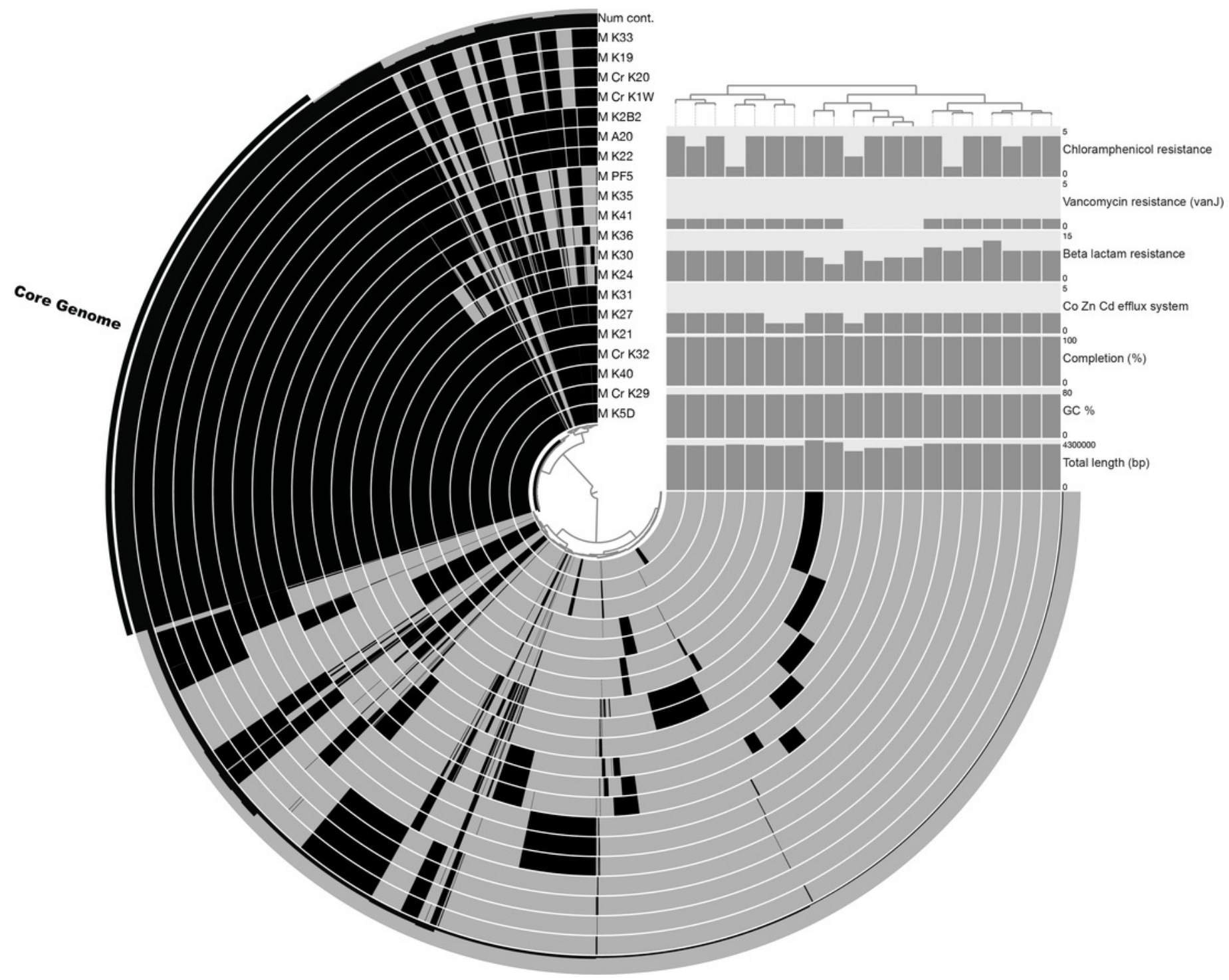




\section{Figure 2}

COGs of share genes

COG distribution of genes found in the core and flexible genomes of 20 Microbacterium isolates isolated from heavy metal contaminated soil.

$40 \%$

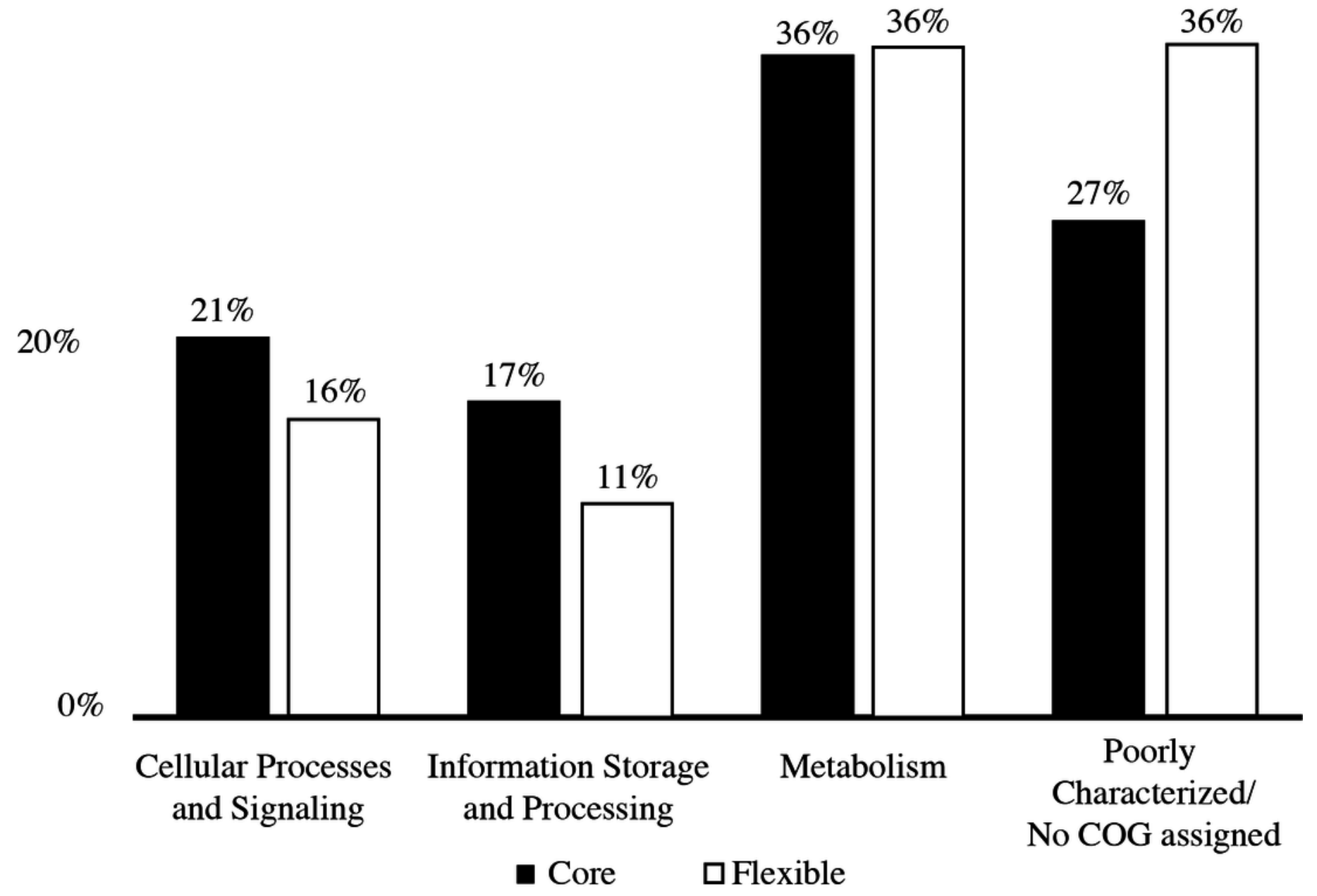

